University of Wollongong

Research Online

Faculty of Social Sciences - Papers (Archive) Faculty of Arts, Social Sciences \& Humanities

2018

Multiscalar governance of urban energy transitions in Australia: The cases of Sydney and Melbourne

Robyn Dowling

University of Sydney

Pauline M. McGuirk

University of Wollongong, pmcguirk@uow.edu.au

Sophia Maalsen

University of Sydney

Follow this and additional works at: https://ro.uow.edu.au/sspapers

Part of the Education Commons, and the Social and Behavioral Sciences Commons

Research Online is the open access institutional repository for the University of Wollongong. For further information contact the UOW Library: research-pubs@uow.edu.au 


\title{
Multiscalar governance of urban energy transitions in Australia: The cases of Sydney and Melbourne
}

\author{
Abstract \\ Sustainable energy transitions - broadly described as moving away from fossil fuels toward renewable \\ resources and reducing energy demand- are emerging across the world, albeit in uneven ways. \\ Scholarship on energy transitions has highlighted the importance of how these transitions may be \\ facilitated or impeded by both governance and politics, and the influence of urban dynamics and histories \\ on these transitions. Using an emphasis on multiscalar governance, this paper analyses emergent energy \\ reconfigurations in Australia, with two purposes. The first is to understand more richly the dynamics that \\ are differentially reworking possibilities for more sustainable energy infrastructure and energy demand in \\ a fossil-fuel dependent nation. Second, we focus on the role of cities, considering the workings of urban \\ energy transitions, most especially through governing the materiality of urban commercial space. Drawing \\ on empirical examples from Australia's two largest cities we suggest that the urban is a crucial nexus \\ through which energy transitions are instigated, manifest and contested. We conclude by confirming that \\ the strategic pursuit of political-economic interests of the urban, in partnership with other state and non- \\ state actors, creates opportunities for energy transitions rendered difficult by institutional and material \\ obduracies.

\section{Disciplines} \\ Education | Social and Behavioral Sciences

\section{Publication Details} \\ Dowling, R., McGuirk, P. \& Maalsen, S. (2018). Multiscalar governance of urban energy transitions in \\ Australia: The cases of Sydney and Melbourne. Energy research and social science, 44 260-267.
}




\title{
Multiscalar governance of urban energy transitions in Australia: the cases of Sydney and Melbourne
}

Robyn Dowling, The University of Sydney, School of Architecture, Planning and Design

Pauline M`Guirk, School of Geography and Sustainable Communities, University of Wollongong

Sophia Maalsen, The University of Sydney, School of Architecture, Planning and Design

Published in Energy Research and Social Science, 44, 260-67

\begin{abstract}
Sustainable energy transitions - broadly described as moving away from fossil fuels toward renewable resources and reducing energy demand-are emerging across the world, albeit in uneven ways. Scholarship on energy transitions has highlighted the importance of how these transitions may be facilitated or impeded by both governance and politics, and the influence of urban dynamics and histories on these transitions. Using an emphasis on multiscalar governance, this paper analyses emergent energy reconfigurations in Australia, with two purposes. The first is to understand more richly the dynamics that are differentially reworking possibilities for more sustainable energy infrastructure and energy demand in a fossil-fuel dependent nation. Second, we focus on the role of cities, considering the workings of urban energy transitions, most especially through governing the materiality of urban commercial space. Drawing on empirical examples from Australia's two largest cities we suggest that the urban is a crucial nexus through which energy transitions are instigated, manifest and contested. We conclude by confirming that the strategic pursuit of politicaleconomic interests of the urban, in partnership with other state and non-state actors, creates opportunities for energy transitions rendered difficult by institutional and material obduracies.
\end{abstract}


Keywords: energy transition; urban; Australia; cities 


\section{Introduction}

In light of the unsustainable nature of current systems of energy provision and use, transitioning away from fossil fuels toward renewable resources and reducing energy demand-sustainable energy transitions-are a crucial global challenge that have excited considerable policy and scholarly attention. The past two decades have seen a proliferation of policies to facilitate such transitions at multiple scales as renewable energy, electricity storage and energy management technologies confront existing energy practices, market structures and businesses models. Addressing diverse aspects of the energy/climate nexus, we see, inter alia, international commitments to carbon reduction targets, national commitments to shifting the energy mix towards renewables, and sub-national alliances of local authorities and community energy initiatives, as well as transnational and transurban networks. Long-established centralized energy systems based on fossil fuels are being socially and materially reconfigured to comply with energy efficiency and decarbonisation (Jaglin, 2013). The city is emerging as an especially salient site in the governance of energy transitions in which the intersections of the politics and materialities of change are manifest (Rutherford and Coutard, 2014; Haarstad, 2016; Webb et al, 2016). Cities' capacities to deliver radical restructuring of energy systems remains in question (Rohracher and Späth, 2014; Monstadt and Wolff, 2015), but their potential contributions to transitions-as catalysts and inhibitors-are accepted. Cities host an intensity of infrastructures, buildings and populations and are crucial sites in which the political dynamics of collusion and collision between incumbent and challenger interests in energy play out (Dodson, 2014; Betsill and Stevis, 2016).

Scholarly entry points on energy transition governance are wide ranging, canvassing, for example, the different domains through which energy governance interventions may occur (e.g. infrastructure, consumption) (Goldthau, 2014; Moss, 2014), ways of understanding governance (Kuzemko et al, 2016; Haarstad, 2016), and the different institutions and actors involved (Emelianoff, 2013; Janda et al., 2016). In this paper we start from a recognition that energy systems are embedded with a multiplicity of social interests that "span across many levels of governance and encompass a wide range of motivations for involvement in reconfiguring energy systems at an urban scale" (Hodson et al., 2013: 1404). Consequently, we investigate the multiple dimensions and multi-scalarity of governance that reconfigure 
energy systems to meet the challenges of decarbonisation, and in so doing, highlight the imbrication of energy transition governance with the politics and materialities of the city (Leck and Simon, 2013; Haarstad, 2016).

This paper investigates this nascent governance of an energy transition in Australia, with particular attention on the role of the urban. We bring to ongoing work on energy transitions two distinct empirical foci. The first is to offer insights from Australia, a nation that is both highly urbanised and highly dependent on fossil-derived energy. In Australia, fossil fuels have underpinned long-term global competitive advantage and economic prosperity ( $\mathrm{M} \subseteq$ Guirk et al., 2014a). The political context is such that energy policy developments have been largely isolated from sustainability considerations and successive national governments have failed to produce a coherent or consistent stance on a low carbon energy future (Warren et al., 2016). The abundant supply of low cost coal has produced a legacy of high carbon intensity electricity generation, still dominated by coal $(63 \%)$ and natural gas $(21 \%)$ and accounting for one third of Australia's carbon emissions (Department of Energy and Science, 2016). Simultaneously, the energy sector contributes 7\% of GDP and is positioned as a major growth sector in the Australian economy (COAG Energy Council, 2015). Energy transitions in Australia, therefore, face tensions around how to preserve the value and economic performance of the current energy regime (AER, 2015). In the context of these tensions, multiscalar governance strategies to facilitate energy transitions in Australia are emerging and, in some senses, proliferating though in fragmented and sometimes contradictory ways (see Mey, Diesendorf and MacGill 2016; Warren et al., 2016). Our second empirical entry point is the Central Business Districts (CBD) of Sydney and Melbourne, within the boundaries of the City of Sydney and City of Melbourne respectively. Though small geographically (the Sydney CBD is 25 square kilometres; Melbourne CBD approximately 30 square kilometres) these are dominated by commercial rather than residential buildings, and thus help shed light on a sector that, in 2013, accounted for just over ten percent of national emissions (ASBEC, 2016: 26). Moreover, the local authorities of Sydney and Melbourne are active and internationally networked in the energy sphere: both are members of C40 and Rockefeller's 100 Resilient Cities (Acuto, 2012). Thus, via a particular focus on these two CBDs, we leverage insights into two important but relatively neglected elements of energy transition governance: (i) the importance of local urban political agenda and materialities (Jensen et 
al., 2016); and (ii) the importance of commercial office buildings, clustered in urban settings and sites of intense energy consumption, as entry points of energy governance intervention (Faulconbridge, 2015).

The paper proceeds as follows. We begin with a review of literature on energy transition governance as multiscalar, conditioned by material and institutional obduracies, and as a domain in which the urban is increasingly recognised as a strategic site. We then turn our attention to the Australian governance context and outline our methodology before turning to empirical analysis. Our empirical analysis focuses, first, on the key conditioning obduracies of the Australian energy system-the National Electricity Market-as the backdrop against which urban energy reconfigurations are being activated. Then we draw the governance processes and multiscaled partnerships through which energy reconfigurations are being catalysed via the material and political capacities of Sydney and Melbourne's CBDs. Our concluding comments reflect on the potential of the urban to create opportunities for energy transitions rendered difficult by institutional and material obduracies.

\section{Governing urban energy transitions: scales, politics and conditioning}

A rich vein of research attempts to understand how, by whom, and through what mechanisms energy transitions are being facilitated. A variety of frameworks are in evidence: Foucauldian governmentality (Bues and Gailing, 2016), the socio-technical transitions perspective (Geels, 2011); and assemblage theory (Haarstad, 2016), to name a few. Common to these frameworks is recognition that governance is not just an activity of the state/government but of diverse assemblages and networks of multi-sector actors, including the private and non-government sector, who increasingly enact the authority to govern ( $M \subseteq$ Guirk and Dowling, 2009). For instance, Hodson and Marvin (2010) explore how city authorities collaborate with various non-state intermediaries to instigate systemic policy changes to secure urban energy supply. Recent scholarship adds a second dimension by recognizing that governing energy transitions is achieved not just through formal politics or regulation but also through manifold social and technical interventions that seek to reshape energy infrastructure and reconfigure energy demand (Bulkeley and Castan-Broto, 2013). There is not the space to comprehensively review and engage with each of these in 
this paper. Rather, drawing on cognate work in the field of climate governance (Bulkeley, 2005; M`Guirk et al., 2014b), our focus is on the multiscalar nature of energy transition governance and the emergent role of the urban within this (Emelianoff 2013; Jaglin, 2013; Haarstad, 2016; Webb et al., 2016). Three points frame our analysis: multiscalar, nonhierarchical intersections of scale; politics; and conditioning.

Scales: Rather than viewing multilevel layers of authority as each having its own separate sphere of policy concern (see Horak, 2012), we align with a view of multilevel energy governance that attends to the interplay of action across and between scales, without the expectation that this interplay will be hierarchically structured (Haarstad, 2016; Lee and Koski, 2015). For instance, national government action may seek to advance governance aspirations (or meet obligations such as carbon reduction targets) through state or local government enactment or endorsement. Equally, however, municipalities may advance initiatives, sometimes through transnational networks, aimed to embed their objectives in national policy settings and thus favourably transform the urban context. Likewise states may hinder the roll out of national governance ambitions thought to impinge on regional interests. Indeed, governance actors may operate across scales or 'jump scales' in the context of pursuing particular pathways to transitions (Betsill and Bulkeley, 2006). The inherently fragmentary nature of multiscalar energy governance poses challenges to attempts at purposeful co-ordination and indeed attempts to articulate a common strategic purpose across its diverse actors (Lo, 2014; Jaglin, 2013). Nonetheless the unprecedented governance challenge presented by the complex multidimensional nature of energy transitions, the myriad contested interests and norms involved and the proliferation of new interests and intermediaries means that multiscalar governance is recognised as essential to the efficacy of transitioning (Emelianoff, 2013; Goldthau, 2014).

Politics: The increased liberalisation of energy systems has decreased the capacity of governments to directly orchestrate systems change (Bolton and Foxon, 2013; Goldthau 2014). Nonetheless the capacity to leverage transition is distributed, reflecting energy systems as socio-technical configurations in which "technologies, institutional arrangements, social practices and actor constellations are mutually dependent and coevolve" (Rohracher and Späth, 2014: 3). Thus while existing energy systems may be obdurate and able to exert considerable influence on the direction of change, pressure points emerge at different scales 
as diverse and newly emergent social interests and intermediaries take shape. Normativelyoriented governance literature has tended to interpret these pressure points as resolvable managerially through consensual, integrated policy coordination (Corfee-Morlot et al., 2009). More politicised readings of governance are inclined to recognise tensions across levels, disjunctures between national and local priorities, and the independent pursuit of local energy objectives (Jaglin, 2013; Jorgensen, 2012; Jensen et al., 2016). In this view, cities are seen to be at once deeply dependent on multiscalar policy orchestration if they are to influence energy transitioning (particularly where energy system and utility ownership is not organised at urban-regional scales), yet simultaneously crucial in a political sense: as intermediaries enacting municipal experimentation and institutional innovation, as sites for pro-environment civic action, as nodes of transnational network connections, and as sites for the fluid formation of cross-sectoral and multiscalar interest alliances (e.g. across political institutions, NGOs, global consulting, construction and utility firms) (Webb et al., 2016). They can build discursive and substantive momentum for state and/or national government energy policy responses. In this sense they are "a crucial nexus between different levels of governance...and crucial loci of change within broader transitions" (Rohracher and Späth, 2014: 2). Moreover, cities' impetus to act as a locus of change can be heightened by city authorities' desires to secure enhanced political autonomy and by the intersection of urban political and business élites' transnational political-economic aspirations wherein energy transitioning is aligned with the governance logics of green growth and global competitiveness (Bulkeley et al., 2016, Webb et al., 2016). The diverse pathways of energy transitions taken by different cities are consequences of how scalar coordination or fragmentation plays out, and how these multi-scalar contestations articulate with the specific obduracies and transition opportunities encountered in particular contexts (Emelianoff, 2013; Jaglin, 2013).

Conditioning: energy infrastructure-like that of other large networked infrastructures-is obdurate and resistant to change (Marvin et al., 2011; Monstadt and Wolff, 2015). This obduracy emanates from a number of sources. Energy infrastructure itself is multiscalar. It is materially composed of centralised, regional and local elements. Relatedly, it is embedded in multiscalar systems of regulation and governance. Its provision, governance and transformation involves various scales that require coordination, but in a complex material 
and institutional context in which identifying where and how to intervene poses a challenge (Goldthau, 2014). Obduracy also results from the ways in which energy systems' "mutually reinforcing technological and institutional structures" co-evolve (Rohracher and Späth, 2014: 3; see Marvin et al, 2011). The material structures of energy supply and their underlying rationales co-evolve with governance arrangements that have been formatted to serve them. This obduracy conditions responsiveness to change. It restrains the flexibility of future developments, reinforced by institutional inertia and the power of incumbent resistance (Webb et al., 2016; Monstadt and Wolff, 2015) while simultaneously shaping the nature of opportunities for reconfiguration.

It is at the intersection of obduracy and opportunities for multiscalar orchestration of transitioning that cities are laden with potential. Certainly the multiscalar nature of energy governance and difficulties of coordination feed into system obduracy (Rohracher and Späth, 2014). Yet cities simultaneously offer key sites of governance intervention that potentially leverage transitioning opportunities. Haarstad (2016) highlights how the existing materiality of the city (for instance, its intense clusters of commercial office buildings) conditions practice, on the one hand, contributing to 'carbon lock-in' and infrastructural obduracy yet, on the other, offering multiple opportunities for energy transitions enacted through local intervention and, especially, regulation of the built environment. Even as urban actors struggle to engage with the complex materiality of energy governance (Webb et al., 2016), the potential of the urban as an appropriate political jurisdiction for energy governance arises from urban governments' authority over and competencies in land use planning and building regulation, and thus their capacity to incorporate existing and future urban infrastructures in transformative energy initiatives (Moss and Franchsch-Huidobro 2016). These capacities potentially guide urban governments to work towards energy transition goals, including those set within national and international frameworks (Betsill and Bulkeley, 2006: 141-142). Cities, particularly when supported by enabling actions and financing across scales of government, have strategically significant capacities to disrupt energy infrastructures and to facilitate new energy system transitions.

\section{Governance Context and Methodology}


In the rest of the paper we take up the questions of how, if at all, sustainable energy transitions are being governed in Australia focussed on the salience of the urban. Our analysis is advanced via an empirical focus on energy transition governance in the CBDs of Sydney and Melbourne, and is guided by attention to the multiscalar, political and conditioned contexts through which any such transition must emerge.

Our analysis is based on information collected on the policies and programs relevant to energy transition governance in these two sites, especially those that pertain to commercial office space. Governance initiatives at multiple scales were collected, including those at the federal or national scale, the states of NSW and Victoria, and the City of Sydney and City of Melbourne local government areas. At each scale we began by identifying the range of institutions whose purview might impact on energy transitions and gathered details of relevant programs and initiatives, with a particular focus on those relevant to urban domains and urban built environments. This included policy and programs of government authorities and agencies as well as non-state actors. In total, more than 80 initiatives were identified, which were categorised according to policy and program purpose, initiating and participating actors and institutions, target audiences, sites and objects of intervention, and governance mechanisms.

\section{Tables 1, 2 and 3 about here}

Before moving on to a detailed analysis of these intiatives in terms of the obduracies that condition possibility, their multi-scalar context and their positioning in urban politics, an overview is in order. Tables 1, 2 and 3 provide an overview of the multiscaled ecology of initiatives that frame energy governance for Sydney and Melbourne, dissected according to two key forms of energy reconfiguration identified by Webb et al (2016): infrastructure, and demand reduction through energy efficiency. Infrastructural reconfigurations are those facilitated through alterations in the ways in which energy is generated and distributed. This may involve a shift in the scale at which energy is provided, the substitution of renewables into existing infrastructure, or the introduction of new technologies (e.g. smart meters) to facilitate transitioning, and the institutional transformation involved in such shifts. As seen on Table 1, the Federal Government dominates policies designed to shift the energy system toward renewables. Many work through financial mechanisms. The Clean Energy Finance 
Corporation, Green Power and the Renewable Energy Target, for example, provide financial incentives and market means for households and businesses shifting toward renewable forms of energy, principally wind and solar. Energy efficiency refers to transitioning not toward or away from a particular energy source but through reducing demand for energy from any source, and has long held sway in the Australian context and especially in the building sector (ASBEC 2016; MGuirk et al., 2014a). Here, as evidenced in Table 2, state and local authorities are much more active, with a plethora of strategies focused on energy use in buildings. Within this building focus is a subset of initiatives that set energy efficiency standards for buildings. These are extracted in Table 3. Through guidance on building technologies (especially HVAC), materials used, layout, siting of windows and other architectural and design elements, standards set the energy consumption parameters of a building. Standards schemes are initiated by both government and non-government actors, voluntary and mandated. In the rest of the paper we present a more detailed analysis of this ecology of initiatives in terms of the framework developed in the previous section. We begin by sketching the key institutional obduracies that are conditioning transition in the energy system, and then turn to the ways in which situated urban actors and multi-scalar partnerships are shaping an energy transition in the two cities.

\section{Conditioning, Scale and Urban Politics in Sydney and Melbourne Energy Transitions}

\subsection{Conditioning: the 'National' Energy Market}

Energy transitions in Australia must contend with the Australian National Electricity Market (NEM) - the socio-technical configuration that frames the energy system. The NEM is both a set of regulated energy markets (wholesale and retail) and a transmission and distribution grid: one of the world's longest interconnected power grids ${ }^{1}$. The NEM emerged out of the progressive liberalisation and privatisation of state-based and state-owned electricity systems in 1998, and is a centrally-regulated means of nationally coordinated, centralised system of electricity generation, trading and supply, under market competition logics. It

\footnotetext{
${ }^{1}$ Despite its name, the NEM covers most but not all of Australia. It serves 10 million homes and businesses across all states except Western Australia and Northern Territory, covering nearly $5000 \mathrm{kms}$. It accounts for approximately $90 \%$ of total national electricity consumption.
} 
includes 200 large generators and 13 major distribution networks across five state-based transmission networks. Reflective of the diverse and contested interests that constitute energy markets and infrastructures in Australia, the NEM sets out a complex regulatory and institutional environment ${ }^{2}$ to coordinate and regulate centralised electricity generation, pricing and supply (see Figure 1). The NEM, quite simply, is, and constructs, an energy system that is socio-technically, institutionally and economically complex.

Figure 1 about here

This complexity means that the NEM acts as both barrier to and catalyst of urban energy transitioning in Australia. A combination of its centralised configuration, excessive reliability standards, guaranteed and elevated network access fees and lack of clarity around connecting embedded generation into the grid have discouraged decentralised or alternative generation and distribution arrangements (Riesz et al., 2014). The electricity tariff system it oversees has yet to fully adopt cost-reflective pricing, and access to energy-use information is still tightly controlled and inadequately available to consumers (EEC, 2012; AEMC, 2012). The sheer regulatory/institutional complexity of the NEM, its predominantly centralised generation and distribution models, and the multiple contested interests it negotiates has produced an inertia that favours socio-technical obduracy. This obduracy has sustained a centralised generation system embedded with fossil-fuel dependence, particularly as it has coincided with a Federal government whose energy policy agenda is driven by logics of market competition and energy productivity rather than a clean energy agenda (Warren et al., 2016). The NEM constrains radical redesign, re-scaling or the redistribution of roles and responsibilities within the energy system. Addressing these constraints would rely not only on legal and technical capacity, but also on savvy political leadership in navigating the vested interests the NEM represents (Baker, 2011). Moreover, aspirations of urban local government to reconfigure the energy system, such as through various forms of microgeneration, are shaped by the institutional and material obduracy of the energy generation and distribution network. The NEM conditions the trajectories of energy system change, and has thus far proved resistant to steering toward sustainable

\footnotetext{
${ }^{2}$ The regulatory framework for the NEM works across rule-making, rule enforcing and market operating bodies: respectively the Australia Energy Market Commission (AEMC), Australian Energy Regulator (AER), and Australian Energy Market Operator (AEMO), which is 60/40 percent government/industry owned.
} 
configurations of the energy system. Nonetheless, the efficacy of a socio-technical system like the NEM to condition energy transitions is never complete but is both reproduced and contested through socio-material and institutional networks (see Hommels 2005). Thus in the remainder of the paper we consider energy transition in and through the NEM, fostered by, and proceeding in, the cities of Melbourne and Sydney.

\subsection{Multi-scalar context and partnerships}

The governance of energy efficiency is characterised by, and constitutive of, multiscalar actor networks. Crucially, these are not hierarchically driven but have emerged from and are built across national, state and urban interdependencies. The numerous national scale programs, such as the National Strategy on Energy Efficiency and the National Partnership Agreement on Energy Efficiency (see Table 2) not only set parameters to foster energy efficient practices across households and businesses, but do so through the establishment of formal agreements across national and state governments. Moreover, state responsibility and authority for energy efficiency transitions in Australia draws heavily upon these national frameworks. For example, the NSW government's 'Energy Saving Scheme', a scheme which uses a financial incentive to reduce electricity consumption, is designed to complement the federal government's national carbon reduction schemes, such as the Carbon Offset Standard. In another example, Melbourne's Inner Melbourne Action Plan (IMAP) is a collaboration of municipal councils encouraging and implementing sustainable development to increase urban liveability, including via energy demand reduction. The IMAP partnership established 11 regional strategies and 57 actions to attain these objectives, requiring the networked cooperation of the State Government, government agencies and private industry, as well as changes to planning schemes requiring statutory approval (IMAP, 2016).

These multiscalar and multiinstitutional networks also act upon and through the materiality of these CBDs, specifically commercial office buildings. A multi-institutional partnership example is the Better Buildings Partnership (BBP) program. The BBP operates in Sydney as a collaboration of local and state government, industry (large-scale commercial office building owners) and research institutions. The BBP provides information on improving building environmental performance, fosters technological innovation and promotes legal 
innovations such as a new legal instrument - green lease - to help building tenants influence the environmental performance of the buildings they occupy (Janda et al., 2016).

Building standards pertaining to the commercial office sector are also orchestrated through multiscalar interactions (see Table 3). Two means of certifying and measuring building energy performance predominate: the state initiated and maintained National Built Environment Rating System (NABERS), and the business sponsored and administered Green Buildings Council of Australia (GBCA) Green Star ratings program. Building energy performance standards are not unique, with voluntary schcemes like the GBCA program found in diverse jurisdictions globally. Notable in Australia is the enveloping of NABERS across a number of jurisdictions and regulatory regimes. For example, the national Building Energy Efficiency Disclosure Act 2010 (Commonwealth) required that commercial office buildings with tenanted areas greater than 2000 square metres $^{3}$ disclose a NABERS rating on lease or sale. Likewise, local government programs create communities of practice around improving NABERS ratings. CitySwitch, for example, was established as a partnership of local and state authorieis and provies a range of activities to encourage energy efficieny in building occupancy. NABERS is woven through these services, such as a discount offered on the NABERS administration fee, or one-on-one support in setting and achieving specific NABERS targets.

In short, the setting, monitoring and publicising of building energy efficiency mobilises urban materiality as a critical means of governing to reduce energy demand and advance energy efficiency as a selective route toward energy transitions. Urban actors in some cases lead these partnerships, in other cases become linchpins of energy transitions as conduits of information and resources. There is, however, differential capacity of urban actors to leverage energy transition through partnership. CitySwitch, for example, is widely acknowledged as being more successful in Sydney than Melbourne, which can be attributed to both its heightened visibility in Sydney and its connections with other City of Sydney programs.

\footnotetext{
${ }^{3}$ Changed to 1000 sqm in 2017.
} 


\subsection{Urban Politics: Reconfiguring Electricity Infrastructure}

It is in the reconfigurations of energy infrastructure that urban politics, political capacity and agency are most pronounced. On the one hand, the national and state policy levers to encourage renewal energy are remarkable for their lack of urban emphasis both in terms of implementation and outcome. The Renewable Energy Target for example, has underpinned phenomenal growth in the installation of solar PV across the country, with more than 1.5 million systems installed by March 2016 (Climate Council, 2016). Yet uptake has been far stronger in rural and regional areas and lower income outer metropolitan suburbs (REC Agents Association, 2012). There is also a pronounced lack of policy recognition of cities, especially in national level governance initiatives. For example, initiatives like the Solar Town Program prioritized regional and outer metropolitan sites, as did the National Community Energy Strategy (see Table 1). Many reasons underpin the relative neglect of the urban in national energy reconfigurations, including a longstanding absence of cities in Australian policy discourse (Gleeson, 1998), the politically sensitive positioning of rural and regional places in national politics (O'Neill and $M \subseteq$ $-G$ uirk, 2007), and the inherent difficulties of integrating distributed solar in cities (Bulkeley et al., 2016). A combination of the institutional-material rigidity of the NEM along with a neglect of cities in national policies conditions and limits mobilization of the potential of urban energy transitions in Australia.

Nonetheless, cities have come to the fore as key sources es of political capacity, asserting significant governance authority and building momentum towards enacting selective, locally contingent transition options (see Jensen et al., 2016). Two examples are illustrative of different urban capacities and processes. The first is the attempt of the City of Sydney to change the NEM rules, including through their participation in multiscalar partnerships. Building on its actions as a member of the C40 group of cities (Davidson and Gleeson, 2015), in 2012 the City of Sydney embarked upon a comprehensive planning strategy in which energy infrastructure transition was a centrepiece. This included a renewable energy strategy that provided for decentralised provision of electricity within the city boundaries. In essence, the plans encouraged the decentralisation of energy infrastructure through the installation not only of roof top solar where possible, but also trigeneration and/or cogeneration plants within or across commercial buildings. As the plan was rolled out, the role of the NEM in hindering implementation became apparent, and in particular in creating 
barriers to local electricity generation and the sharing of this electricity across properties. In response, a request to change the rules of the NEM was submitted, aiming to alter the economic credit available to local generators of electricity and charges to access a network. It is not our intention to unravel the complexity of the rule change request here. Rather, we highlight its pertinence to the urban and multiscalar (and multi-institutional) governance of energy transitions.

First, the rule change request emanated from a partnership between the City, a local environmental protection action group (The Total Environment Centre), and the peak industry advocacy organisation for the property development industry (the Property Council of Australia). These, especially the latter two, are unlikely partners, but there was a placespecifc alignment of interests - the Total Environment Centre in fostering a broad shift to renewables and the Property Council in fostering the economic benefits of local generation. Second, it is illustrative of the capacity of urban actors to lead business as well as other governments in leveraging energy transitions through infrastructural reconfiguration ${ }^{4}$. As the reasons articulated by the City of Sydney make clear:

Changing rules to encourage more local power generation will improve energy efficiency, curb emissions and reduce network maintenance costs...It is essential the regulatory environment acts to stimulate innovation and set a platform for the property industry to play its part in building better cities. (Moore, 2015)

The system imperatives created by the City's planning strategy, combined with strong partnerships, led to the request. Third, the request strongly articulates the locally-defined issues that shape the City of Sydney's urban politics. The Sustainable Sydney 2030 plan, for instance, lays out a political agenda of becoming 'green, global, and connected' in ways that append sustainability goals to an agenda of global urban competitiveness and enhancing Sydney's ranking in global city league tables for Sydney (Acuto, 2012). In this light, the rule change request allowed the City to demonstrate leadership in energy transition in line with its aspirations to be 'internationally recognised as a leader with outstanding environmental performance and new 'green' industries driving economic growth' (City of Sydney, n.d.).

\footnotetext{
${ }^{4}$ While this rule change request was denied by Australian Energy Market Commission (AEMC), its proponents announced very quickly following the AEMC's ruling that a second request would be formally launched.
} 
Though the attempt was ultimately unsuccessful, the point remains: energy transitions emerge from the particularities of context and the assertion of the political authority to act by city governments.

An allied but distinctive Melbourne example of the political capacity of the city to leverage energy transition is the Melbourne Renewable Energy Plan. MREP is a procurement plan conceived and managed by the City of Melbourne (CoM) local authority. In it, 14 councils, cultural institutions and corporations collectively purchase renewable energy from a newlybuilt wind farm. The construction and finance of the plant itself is enabled by the revenue certainty provided by a long-term power purchase agreement (PPA), co-ordinated by CoM, in which the partners sign on to purchase half of the plant's 80MW generation capacity.. The partners' enthusiasm to sign PPA contracts is conditioned by their need to secure cost stability and hedge risk associated with volatile energy markets and rising prices produced by the changing energy mix, institutional and infrastructural obduracy of the Australian National Energy market. Both CoM and Yarra councils have committed to purchase $100 \%$ of their energy needs via MREP, contributing heavily towards their aspiration to be net zero by 2020.

MREP is a product of the multiscalar configuration of energy supply and energy politics. Its conception by CoM is, in the words of Deputy Mayor and MREP champion Aaron Wood, "a product of a policy vacuum on national transition away from carbon-based electricity production" (Walhquist 2017). Wood went on to quip "Nations talk, cities Act (citing Michael Bloomberg ${ }^{5}$ ). We don't often talk about government being the innovators but this is a really innovative project driven by the City of Melbourne". The political capacity of the city to "force the issue", as one interviewee put it, by leveraging new alliances across scales and sectors and operate as a pressure point in the obdurate energy system has been publicly recognised by the $\mathrm{C} 40$, whose executive director has acknowledged the plan as "creat(ing) a guaranteed market for renewable energy that makes a renewable plant look like a great investment for energy companies...it's the kind of innovation and collaboration that's making cities and mayor such exciting leaders in the climate change field" (Walhquist

\footnotetext{
${ }^{5}$ UN special envoy for Cities and Climate Change and former chair of the C40 Leadership Group.
} 
2017). It is important to note the breadth and complexity of the MREP orchestrated by the City of Melbourne. Signatories included city and regional councils, major universities, major land and property holders across the city, financial institutions, corporations and cultural institutions. The City hence negotiated across diverse interests arising from the different energy profiles, scales of operation, CSR and other priorities of the signatories, as well as the complexities embedded in the NEM's regulatory framework and the wider policy context. As in the City of Sydney example, the political capacity of the City of Melbourne was used to draw together diverse groups to achieve a renewable energy solution unique to the materiality of the CBD. While in Sydney the imperative was on-site generation because of the City's commitments to tri- and co-generation, in Melbourne the solution was networked generation. The materiality of the CBD, and in particular the inadequacy of roof top solar, shaped the general response, but urban politics shaped the specific response, with the City of Sydney's global environmental aspirations manifest in a bold attempt to change the rules of the game.

\section{Conclusion}

Policy, institutional, and socio-technical frameworks for energy transitions in Australia are fractured yet productive. An attention to scale, politics and conditioning helps reveal the role of the urban in leveraging these transitions. There is an institutional and infrastructural obduracy to the electricity market and grid that favours a 'structural conservatism' (Monstadt and Wolff, 2015) that stabilises fossil fuel-based, large-scale generation. Infrastructure reconfigurations are both underdeveloped and have a limited role for the urban. Yet, energy systems are dynamic, dependent on multiscalar governance, and invite reform. It is in these reform efforts that we can locate a specific role for the urban, despite the limited urban capacity for direct governance intervention in the energy system.

In terms of the paper's contribution to understandings of the role of the urban in energy transition, our analysis of the Australian case sheds light on Rohracher and Späth's (2013: 2) question, to what extent can the local infrastructures, socio-technical constellations and energy visions that elicit energy transition be shaped and stabilised at the urban scale, when energy's networked material and institutional infrastructures reach far beyond the city 
itself? In the Australian case, energy efficiency arises as a highly active space of reconfiguring energy demand, conditioned by the infrastructural and institutional obduracies of the NEM. Interest in advancing energy efficiency in the urban built environment aligns with the political-economic interests of the property industry and facilitates the cohering of alliances of common interest (such as Sydney's Better Buildings Partnership). Such alliances, in turn, have implications for reinscribing urban political economies and ecologies of energy. Simultaneously, we have shown how urban-based political drivers (such as local authorities' multifaceted priorities and the property sector's economic interests in the benefits of sustainable energy) are creating political momentum towards particular kinds of infrastructural reconfiguration. Cities are pushing the energy envelope, constituting diverse partnerships across scales with other cities and other levels of government to pursue their own renewable energy priorities in the absence of a broader multiscale policy consensus. Through leveraging multilevel strategies, actor networks and the materialities of the urban built environment, cities produce urban capacity for energy transitions and, in so doing, build or buoy their legitimacy and autonomy (Emelianoff, 2013). In sum, the Australian case suggests that new urban partnerships and activities are creating opportunities for energy transitions rendered difficult by institutional and material obduracies.

\section{References}

Australian Energy Market Commission, 2012, Power of Choice Review -Giving Consumers Options in the Way they Use Electricity, Final Report, 30 November 2012, Sydney

Australian Energy Regulator, 2015, State of the Energy Market, Australian Competition and Consumer Commission, Commonwealth of Australia, Canberra

Australian Sustainable Built Environment Council, 2016, Low Carbon, High Performance. http://www.asbec.asn.au/wordpress/wp-content/uploads/2016/05/160509-ASBECLow-Carbon-High-Performance-Full-Report.pdf. Accessed Nov 152017 
Acuto M, 2012, “Ain't about politics? The wicked power-geometry of Sydney's greening governance" International Journal of Urban and Regional Research 362 381-399

Baker L, 2011, "Governing electricity in South Africa: wind, coal and power struggles." Working Paper No. 015, The Governance of Clean Development Working Paper Series, University of East Anglia

Betsill M, Bulkeley H, 2006, "Cities and the multilevel governance of global climate change" Global Governance 12 141-159

Betsill M, Stevis D, 2016, "The politics and dynamics of energy transition: lessons from Colarado's (USA) 'New Energy Economy'” Environment and Planning C, 34 381-396

Bolton R, Foxon RT, 2013, “Urban infrastructure dynamics: market regulation and the shaping of district energy in UK cities" Environment and Planning A 45 2194-2211

Bues A, Gailing L., 2016, “Energy transitions and power: between governmentality and depoliticization" In L Gailing and T Moss (Eds) Conceptualizing Germany's Energy Transition. Springer, 69-91

Bulkeley H, 2005, "Reconfiguring environmental governance: Towards a politics of scales and networks" Political Geography 24 875-902

Bulkeley, H., Castán Broto, V., 2013, "Government by experiment? Global cities and the governing of climate change." Transactions of the Institute of British Geographers, 38(3), 361-375

Bulkeley H., Luque-Ayala A, McFarlane C, 2016, “Enhancing urban autonomy: towards a new political project for cities" Urban Studies, 1-18

Climate Council, 2016, Renewable Energy Jobs: Future growth in Australia, Climate Council of Australia, Potts Point.

City of Sydney, (n.d.), Sustainable Sydney 2030,

http://www.cityofsydney.nsw.gov.au/vision/sustainable-sydney-2030. Accessed Nov 112017.

COAG Energy Council, 2015, Energy Market Reform Bulletin No.40: Release of Final Report Review of Governance Arrangements for Australian Energy Markets, 
http://www.coagenergycouncil.gov.au/publications/energy-market-reform-bulletinno40-release-final-report-review-governance-arrangements. Accessed 11 Nov 2017. Corfee-Morlot J, Kamal-Chaoui L, Donovan MG, Cochran I, Robert A, Teasdale PJ, 2009, Cities, Climate Change and Multilevel Governance OECD Environment Working Papers, 14, OECD Publishing, Paris

Davidson K, Gleeson B, 2015 “Interrogating Urban Climate Leadership: Toward a Political Ecology of the C40 Network" Global Environmental Politics 15 21-38

Department of Energy and Science, 2016, "Australian Energy Update", Commonwealth of Australia. https://industry.gov.au/Office-of-the-Chief-

Economist/Publications/Documents/aes/2016-australian-energy-statistics.pdf. Accessed April 82018

Dodson J, 2014, Suburbia under an energy transition: A socio-technical perspective Urban Studies 51 1487-1505

Emelianoff C, 2014 “Local energy transition and multilevel climate governance: The contrasted experiences of two pioneer cities (Hanover, Germany, and Växjö, Sweden)" Urban Studies 51 1378-1383

Energy Efficiency Council, 2012, Plan for Affordable and Efficient Energy. http://www.eec.org.au/news/eec-news/article/joint-statement-a-plan-foraffordable-energy. Accessed Nov 112017.

Faulconbridge J, 2015, “Mobilising sustainable building assessment models: agents, strategies and local effect" Area 27 116-123

Geels F, 2011, "The multi-level perspective on sustainability transitions: responses to seven criticisms" Environmental Innovation and Societal Transitions 1 24-40

Gleeson B, 1998, "The resurgence of spatial planning in Europe" Urban Policy and Research $16219-225$

Goldthau A, 2014, "Rethinking the governance of energy infrastructure: scale, decentralization and polycentrism" Energy Research and Social Science 134-140

Haarstad H, 2016, "Where are energy transitions being governed? Conceptualizing the complex governance arrangements for low-carbon mobility in Europe" Cities 54 4- 
Hodson M, Marvin S, 2010, "Can cities shape socio-technical transitions and how would we know if they were?" Research Policy 39 477-485

Hodson M, Marvin S, Bulkeley H, 2013, "The intermediary organisation of low carbon cities: a comparative analysis of transitions in Greater London and Greater Manchester" Urban Studies 50 1403-1422

Horak M, 2012, Conclusion: understanding multilevel governance in Canada's cities, in: M. Horak and R. Young (Eds) Sites of Governance: Multilevel Policy-making in Canada's Cities; Montreal: McGill-Queens Press.

IMAP, 2016, About IMAP http://imap.vic.gov.au/index.php?page=about-imap. Accessed 4 Nov 2017

Jaglin S, 2013, "Urban energy policies and the governance of multilevel issues in Cape Town" Urban Studies 50 1394-1414

Janda K, Bright S, Patrick J, Wilkonson S, Dixon T, 2016, “ The evolution of green leases: towards inter-organisational environmental governance" Building Research and Information 44 5-6 660-674

Jensen JS, Fratini CS, Cashmore MA, 2016, "Socio-technical systems as place-specific matters of concern: the role of urban governance in the transition of the wastewater system in Denmark" Journal of Environmental Policy \& Planning 18 234-52

Jorgensen, U. 2012 “Mapping and navigating transitions - The multi-level persepective compared with areas of development" Research Policy, 41 996-1010.

Kuzemko C, Lockwood M, Mitchell C, Hogget R, 2016, " Governing for sustainable energy system change: Politics, contexts and contingency" Energy Research and Social Science 12 96-105

Leck H, Simon D, 2013, "Fostering multiscalar collaboration and co-operation for effective governance of climate change adaptation" Urban Studies, 50 1221-1238

Lee T, Koski C, 2015, “Multilevel governance and urban climate change mitigation” Environment and Planning C 331051-1517 
Lo K, 2014, "Urban carbon governance and the transition toward low-carbon urbanism: review of a global phenomenon" Carbon Management 5 269-283

M`Guirk PM, Dowling R, Bulkeley H, 2014a “Repositioning urban governments? Energy efficiency and Australia's changing climate and energy governance regimes" Urban Studies, 51, 2717-2734

M`Guirk PM, Bulkeley H, Dowling R, 2014b, “Practices, programs and projects of urban carbon governance: perspectives from the Australian city" Geoforum 52 137-147

MGuirk PM, Dowling R, 2009, “Neoliberal privatisation? Remapping the public and private in Sydney's masterplanned residential estates" Political Geography, 28 174-185

Markard J, Raven R, Truffer B, 2012 "Sustainability transitions: an emerging field of research and its prospects" Research Policy 41 955-967

Marvin S, Guy S, Medd W, Moss T, 2011, Shaping Urban Infrastructures: Intermediaries and the Governance of Socio-Technical Networks. Earthscan, New York

Mey, F, Diesendorf, M, MacGill, I, 2016, “Can local government play a greater role for community renewable energy? A case study from Australia." Energy Research \& Social Science 21 33-43

Monstadt J, Wolff A, 2015, “Energy transition or incremental change? Green policy agendas and the adaptability of the urban energy regime in Los Angeles" Energy Policy 78 213-224

Moore C, 2015, "Breaking news: City of Sydney, Property Council and TEC team up on energy" The Fifth Estate http://www.thefifthestate.com.au/innovation/energy/breaking-news-city-ofsydney-property-council-tec-team-up-on-energy-2/79816/comment-page-1., Accessed 15 Nov 2017

Moss T, 2014, "Socio-technical change and the politics of urban infrastructures: Managing energy in Berlin between dictatorship and democracy" Urban Studies 51 1432-1448

O’Neill PM, M`Guirk PM, 2007 “Reterritorialisation of economies and institutions: the rise of the Sydney basin economy" Space and Polity 9 283-305 
REC Agents Association 2012, Research note: geographical analysis of solar systems under the renewable energy target.

http://greenmarkets.com.au/images/uploads/GEM\%20Reports/Industry\%20Reports Research Note No 3 - Geographical Summary Sep 2012 Final.pdf Accessed Nov 152017.

Riesz, J., Hindsberger, M., Gilmore, J. and Riedy, C, 2014, 'Perfect storm or perfect opportunity? Future scenarios of the electricity sector and their implications for utilities' in Distributed Generation and its Implications for the Utility Industry, Academic Press 453-474

Rohracher H, Späth P, 2014, "The Interplay of Urban Energy Policy and Socio-technical Transitions: The Eco-cities of Graz and Freiburg in Retrospect" Urban Studies B 14151431

Rutherford J, Coutard O, 2014, “Urban energy transitions: Places, processes and politics of socio-technical change" Urban Studies 51 1353-1377

Rydin U, Turcu C, Guy S, Austin P, 2013, "Mapping the coevolution of urban energy systems: pathways of chang" Environment and Planning A 45 634-649

Vertigan M, Yarrow G, Morton E, 2015, Review of Governance Arrangements for Australian Energy Markets. Commonwealth of Australia, Canberra

Wahlquist C, 2017, Melbourne consortium underwrites windfarm in Australian-first deal, The Guardian 23 Nov, https://www.theguardian.com/australianews/2017/nov/23/melbourne-consortium-underwrites-windfarm-in-australianfirst-deal

Warren B, Christoff P, Green D, 2016, “Australia's sustainable energy transition: The disjointed politics of decarbonisation" Environmental Innovation and Societal Transitions 21 1-12

Webb J, Hawkey D and Tingey M, 2016, “Governing Cities for sustainable energy: The UK case" Cities 54 28-35

Wood T, 2015, “Energy policy and stability: a contradiction in terms?" Paper presented to NEM Future Forum, 25 June 2015, Sydney 


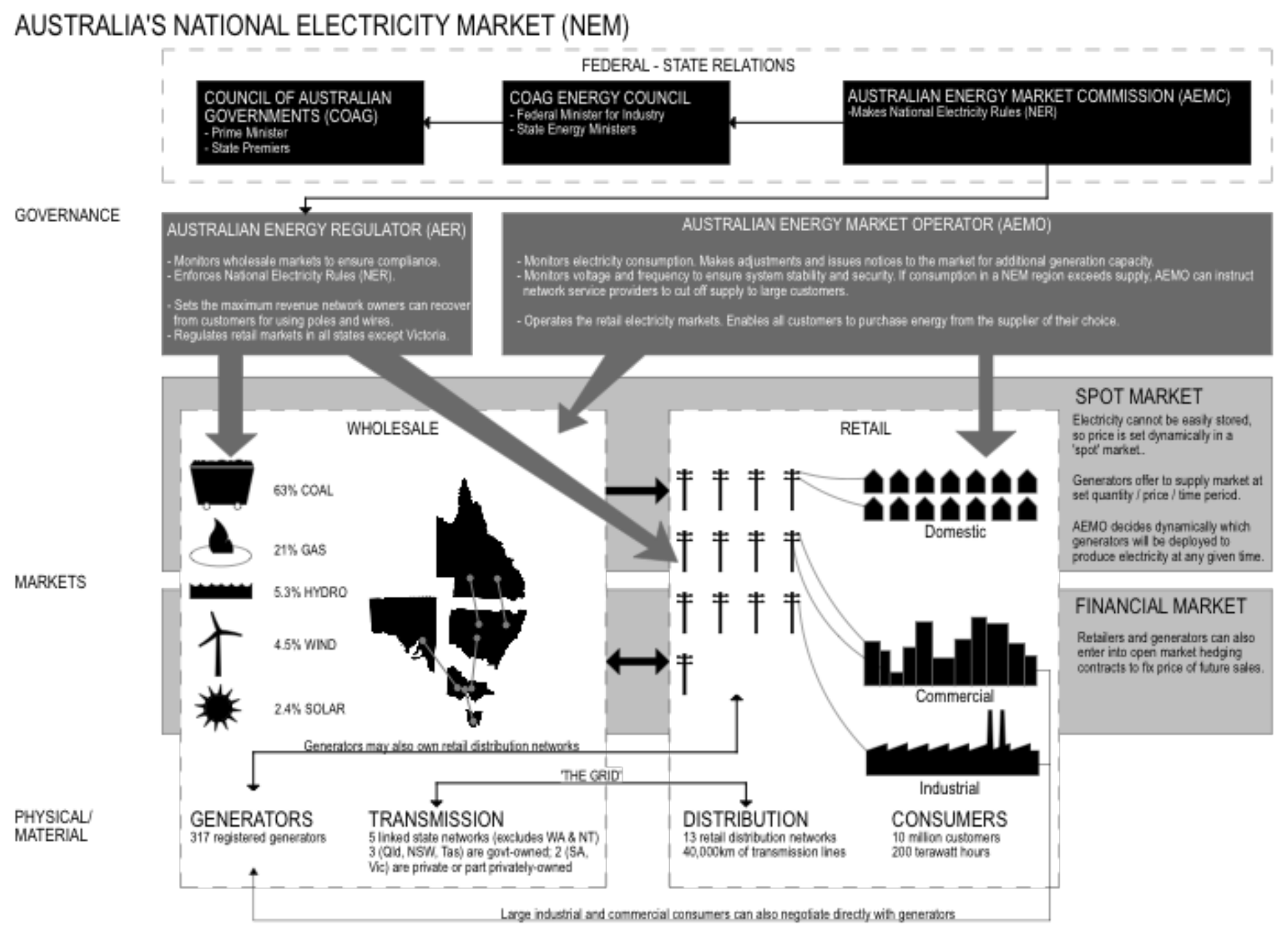

Figure 1: Australia's National Electricity Market

Table 1: Policies focused on Reconfiguring Infrastructures of Energy Generation and Distribution 


\begin{tabular}{|c|c|c|}
\hline Scale & Program Name & Description \\
\hline \multirow[t]{10}{*}{ Federal } & Energy Market Reform Program & $\begin{array}{l}\text { Multiple reforms focused on strengthening regulation; empowering consumers; enhancing competition } \\
\text { and innovations; ensuring balanced network investment. }\end{array}$ \\
\hline & Energy White Paper & $\begin{array}{l}\text { Strategy to address future challenges to Australia's energy sector through increased competition; } \\
\text { increasing energy productivity; investing in Australia's energy future. }\end{array}$ \\
\hline & GreenPower & Program allows energy companies to purchase renewable energy on the customer's behalf \\
\hline & Renewable Energy Target & $\begin{array}{l}\text { Creation of energy certificates for every megawatt hour of energy produced, which energy retailers } \\
\text { purchase and provide to consumers }\end{array}$ \\
\hline & Solar Towns Programme & $\begin{array}{l}\text { Provides financial support to community organisations to install solar photovoltaic panels or solar hot } \\
\text { water systems on existing buildings }\end{array}$ \\
\hline & $\begin{array}{l}\text { National Community Energy } \\
\text { Strategy: }\end{array}$ & $\begin{array}{l}\text { Supports the development of community owned energy throughout Australia with a focus on } \\
\text { renewable and sustainable energy }\end{array}$ \\
\hline & $\begin{array}{l}\text { National Carbon Offset Standard } \\
\text { Carbon Neutral Program }\end{array}$ & A voluntary scheme in which products, businesses, or events can be certified as carbon neutral. \\
\hline & Emissions Reduction Fund & $\begin{array}{l}\text { Provides financial incentives for emissions reductions. Emission reductions credits can be purchased in } \\
\text { competitive reverse auctions }\end{array}$ \\
\hline & National Energy Productivity Plan & $\begin{array}{l}\text { Economy-wide work plan designed to deliver a } 40 \text { per cent improvement in Australia's energy } \\
\text { productivity. }\end{array}$ \\
\hline & Clean Energy Finance Corporation & $\begin{array}{l}\text { Invests in projects that support renewable energy, energy efficiency, and increase economic } \\
\text { competitiveness }\end{array}$ \\
\hline \multirow[t]{3}{*}{$\begin{array}{l}\text { New South } \\
\text { Wales }\end{array}$} & Renewable Energy Action Plan & $\begin{array}{l}\text { Broad policy to increase renewable energy; outlines } 24 \text { actions under three goals: attract investment in } \\
\text { renewable energy; build community support; and increase renewable energy expertise }\end{array}$ \\
\hline & $\begin{array}{l}\text { Energy Efficiency and Renewables } \\
\text { Finance Guide }\end{array}$ & $\begin{array}{l}\text { Assists consumers to understand the financial options available for energy efficient and renewable } \\
\text { energy }\end{array}$ \\
\hline & Regional Clean Energy Program & $\begin{array}{l}\text { Provides information, resources and funding to support regional communities to undertake local } \\
\text { renewable energy initiatives }\end{array}$ \\
\hline
\end{tabular}




\begin{tabular}{|c|c|c|}
\hline Victoria & $\begin{array}{l}\text { Victoria's Renewable Energy } \\
\text { Roadmap }\end{array}$ & $\begin{array}{l}\text { Informs consultation on the Renewable Energy Action Plan and identifies barriers to renewable energy } \\
\text { development, establish a renewable energy target, support renewable energy projects. }\end{array}$ \\
\hline & Next Wave Report & determines the opportunities for retrofit in the non-premium commercial office building sector \\
\hline & Smart meters & Mandatory upgrade to smart meters for business and households across the state \\
\hline \multirow[t]{4}{*}{$\begin{array}{l}\text { City of } \\
\text { Sydney }\end{array}$} & Renewable Energy Masterplan & $\begin{array}{l}\text { Outlines actions for increasing renewable energy production and use based on existing technologies } \\
\text { and in accordance with the targets set in the Sustainable Sydney } 2030 \text { Plan }\end{array}$ \\
\hline & Trigeneration Master Plan & $\begin{array}{l}\text { Outlines actions for increasing the scale of trigeneration of electricity to supply electricity to the } \\
\text { network increasing energy efficiency and reducing emissions }\end{array}$ \\
\hline & $\begin{array}{l}\text { Decentralised Energy Master Plan } \\
\text { - Renewable Energy 2012-2030 }\end{array}$ & Outlines actions for increasing the scale of renewable energy to supply electricity to the network. \\
\hline & NEM rule change request & $\begin{array}{l}\text { Submission to the NEM to request a rule change to increase the uptake of incentive schemes and to } \\
\text { promote non-network alternatives to network augmentation and replacement }\end{array}$ \\
\hline \multirow[t]{2}{*}{$\begin{array}{l}\text { City of } \\
\text { Melbourne }\end{array}$} & Solar Melbourne Program & $\begin{array}{l}\text { Assists the uptake of solar for businesses by providing free assessments, information, and funding } \\
\text { options through EUAs }\end{array}$ \\
\hline & $\begin{array}{l}\text { Melbourne Renewable Energy } \\
\text { Plan }\end{array}$ & $\begin{array}{l}\text { Partnership and purchasing power agreement between multiple stakeholders to provide renewable } \\
\text { energy }\end{array}$ \\
\hline
\end{tabular}




\section{Table 2: Policies focused on Transitions through Energy Efficiency}

\begin{tabular}{|c|c|c|}
\hline $\begin{array}{l}\text { Scale of } \\
\text { Initiation }\end{array}$ & Name & Description \\
\hline Federal & $\begin{array}{l}\text { National Strategy and National } \\
\text { Partnership on Energy } \\
\text { Efficiency }\end{array}$ & Two related programs to adopt and implement a national approach to energy efficiency \\
\hline \multirow[t]{3}{*}{$\begin{array}{l}\text { New South } \\
\text { Wales }\end{array}$} & $\begin{array}{l}\text { Environmental Upgrade } \\
\text { Agreement }\end{array}$ & $\begin{array}{l}\text { Finance agreements for small business and commercial buildings to improve environmental performance. } \\
\text { Facilitated through local government, with loans repaid through council rates charges }\end{array}$ \\
\hline & Sustainability Advantage & Helps organisations adopting environmental best practice to increase economic performance \\
\hline & Climate Change Fund & Provides funding to support projects designed to improve energy and water management \\
\hline \multirow[t]{4}{*}{ Victoria } & $\begin{array}{l}\text { Environmental Upgrade } \\
\text { Agreement }\end{array}$ & $\begin{array}{l}\text { Finance agreements for small business and commercial buildings to improve environmental performance. } \\
\text { Facilitated through local government, with loans repaid through council rates charges }\end{array}$ \\
\hline & $\begin{array}{l}\text { Council Alliance for a } \\
\text { Sustainable Built environment }\end{array}$ & Municipal alliance that applies ecologically sustainable development through planning systems \\
\hline & $\begin{array}{l}\text { Victorian Adaptation and } \\
\text { Sustainability Partnership }\end{array}$ & State and local government partnership \\
\hline & Sustainability Fund & Funded by revenue from landfill levies to fund projects that encourage sustainable resource use \\
\hline \multirow[t]{2}{*}{ City of Sydney } & Better Building Partnership & $\begin{array}{l}\text { Partnership of local and state government, industry, and research institutions. Aims to reduce barriers to } \\
\text { sustainability \& resource use in commercial buildings to improve environmental performance }\end{array}$ \\
\hline & CitySwitch & $\begin{array}{l}\text { Provides environmental audits of commercial spaces and offers information, expertise, and networking on } \\
\text { how to improve NABERS rating }\end{array}$ \\
\hline \multirow[t]{2}{*}{$\begin{array}{l}\text { City of } \\
\text { Melbourne }\end{array}$} & Inner Melbourne Action Plan & $\begin{array}{l}\text { A coalition of inner city council's working together to address Melbourne's liveability across } 11 \text { regional } \\
\text { strategies and } 57 \text { actions }\end{array}$ \\
\hline & Sustainable Melbourne Fund & $\begin{array}{l}\text { Supports projects that increase economic and environmental value through financial innovation and } \\
\text { sustainable business practice }\end{array}$ \\
\hline
\end{tabular}




\begin{tabular}{|l|l|l|}
\hline CitySwitch & $\begin{array}{l}\text { Provides environmental audits of commercial spaces and offers information, expertise, and networking } \\
\text { opportunities on how to improve their NABERS rating }\end{array}$ \\
\hline
\end{tabular}


Table 3: Transitions through Energy Efficiency: Building Standards

\begin{tabular}{|c|c|c|}
\hline & Program Name & Description \\
\hline \multirow[t]{5}{*}{ Federal } & NABERS & Environmental performance rating scheme for commercial space \\
\hline & Greenstar & Green Building Council of Australia's environmental rating scheme \\
\hline & $\begin{array}{l}\text { Building Energy Efficiency Disclosure } \\
\text { Act }\end{array}$ & $\begin{array}{l}\text { Mandates the provision of energy efficiency information and a Building Energy Efficiency } \\
\text { Certificate for commercial office spaces } 2000 \text { sqm and above which are being sold or leased. } \\
\text { Established the Commercial Building Disclosure Program. }\end{array}$ \\
\hline & $\begin{array}{l}\text { Commercial Building Disclosure } \\
\text { Program }\end{array}$ & $\begin{array}{l}\text { Mandates disclosure of energy efficiency information for commercial spaces }>2000 \text { sqm when } \\
\text { offered for sale or lease }\end{array}$ \\
\hline & National Construction Code & $\begin{array}{l}\text { Regulates construction by state and Territory governments. Section J pertains to minimum } \\
\text { energy efficient measures. }\end{array}$ \\
\hline $\begin{array}{l}\text { New South } \\
\text { Wales }\end{array}$ & No more average buildings in NSW & $\begin{array}{l}\text { Financial support to improve the energy efficiency of commercial buildings which have a three } \\
\text { stars or less NABERS energy rating. }\end{array}$ \\
\hline Victoria & $\begin{array}{l}\text { Efficient Government Buildings } \\
\text { Program }\end{array}$ & Implements energy efficiency retrofits to save energy costs in government buildings \\
\hline \multirow[t]{2}{*}{$\begin{array}{l}\text { City of } \\
\text { Melbourne }\end{array}$} & $\begin{array}{l}\text { Melbourne Planning Scheme } \\
\text { Amendment }\end{array}$ & Applies specific standards for resource efficiency and environmental performance to new builds \\
\hline & $\begin{array}{l}\text { Energy, Water and Waste Efficiency } \\
\text { Policy }\end{array}$ & Applies industry-recognised standards for energy, water and waste to new buildings \\
\hline
\end{tabular}

